\title{
STUDIES ON THEILERIOSIS IN CROSSBRED CALVES BEFORE AND AFTER TREATMENT BY BUPARVA- QUONE UNDER THE EFFECT OF LOCAL CONDITIONS IN UPPER EGYPT.
}

\author{
M. Abdel-Salam and M. W. Ghattas* \\ *Animal Health Research Institute, Port Said Regional Laboratory.
}

\begin{abstract}
This study aimed to estimate the drastic effects of Theileria annulata infection on the general health condition and some haematological and biochemical parameters and to evaluate the efficacy of Buparvaquone in treatment of crossbred calves. Bup-arvaquone was injected at a dose rate of $2.5 \mathrm{mg} / \mathrm{kg} \mathrm{BW}$ as a single dose (group A) or double doses with $48 \mathrm{~h}$ intervals (group B).The rate of Parasitaemia in the infected calves reached 12-28\%.Pyre-xia reached $40.5-41.3{ }^{\circ} \mathrm{C}$. Anaemia was a hallmark of the disease accompanied by reduction of the mean values of blood serum total protein, albumin, globulin, glucose, cholesterol, calcium, and phosphorous while non significant changes in the concentrations of blood serum triglycerides and magnesium were recorded if compared to the non infected control calves (group C). Animals in group A showed elevated rectal temperature $\left(40-40.6{ }^{\circ} \mathrm{C}\right)$ for $5-8$ days and the rate of parasitaemia declined slowly till it reached its minimal level $(4.5 \%) 20$ deys post treatment (PT). Also, 2 calves were died at the day 7 and $8 P T$ with high rate of parasitaemia (33-41\%) and pyrexia $\left(41.6^{\circ} \mathrm{C}\right)$. In group $B$, the temperature subsided 1-2 days after the 2 nd dose and the rate of parasitaemia reached to less than $1 \%$ at the day 12. Haematological parameters remained reduced $P T$ in group A, while they restored their normal values except total leucocytic count in group $B$. Biochemical parameters were restored except serum globulin concentration in group $B$, whih remaind in group $A$. From these investigations we can concluded that buparvaquone at a dose rate $2.5 \mathrm{mg} / \mathrm{kg} \mathrm{BW}$ in double dose with $48 \mathrm{~h}$ intervals is more efficient than a single dose under the local environment of Upper Egypt.
\end{abstract}




\section{INTRODUCTION}

Thetick-borne protozoan parasite, Theileria annulata,causes a drastic disease in Friesian cattle which imported to improve productivity in alarge area of the world (Urquhart et al, 1996).

The disease appears to be endemic in Egypt causing great economic losses in animal production (Daubney and Sami, 1951).

Tropical theileriosis can be controlled by management and movement control together with vector control through application of acaricides, treatment of clinical cases by using specific chemotherapeutics; immunization and selecting of cattles resistant to ticks or the disease (Brown, 1990).

The chemotherapeutic erradication of the disease included the use of oxytetracycline, halofuginone lactate, imidocarb dipropionate, parvaquone and buparvaquone (Refaii and Michael,1976and Singh etal.,1993a).

Uptillnow Buparavaquone (2-(Trans- 4 -t - butylcyclohexy-lmethyl) -3-hydroxy-1,4-naphthoquinone) is the drug of choice in the treatment of theileriosis (Singh et al., 1993 a, b and Radostits, et al., 2000).

However, the drug buparavaquone in a single dose of $2.5 \mathrm{mg} / \mathrm{kg} \mathrm{BW}$ may be satisfactory(Sharma and Mishra,1990,Dhar et al.,1990and Singh et $\boldsymbol{a l}$. 1993a,b) or unsatisfactory and haematinics must be needed (Dhar et al., 1988).

In spite of the prevention of severe illness induced by parasites throughout therapeutic medications is perhaps less ambitious than developing vaccination strategies, but at least up till now it might be a more realistic approach (Volker et al., 2001).

The present work aimed to estimate the hazard effects of Theileria annulata infection on some haematological and biochemical parameters in crossbred calves and to evaluate the effect of the drug buparvaquone in two ways either by single or double doses on the pattern of these parameters. 


\section{MATERIALS AND METHODS}

In a Theileria annulata endemic area at Sahel Saleem, Assiut Governorate, a total number of 25 crossbred (Friesian x Balady) male calves aged 8-12 months were examined clinically and classified into 3 groups. Infected and non infected groups according to body condition, rectal temperatures, superficial lymph nodes and visible mucous membranes, as well as parsitological examination. The infected animals were subdivided into two groups. Group (A) consisted of 10 animals and group (B) 8 calves. The non infected group was 7 healthy parasitic free calves.

\section{- Sampling and parasitological examinations:}

Blood smears were taken from the peripheral blood of the investigated animals, before treatment and every 4 days after treatment for 20 days dried in air, fixed with absolute methanol, stained with $10 \%$ Giemsa stain (Levine, 1985) and examined microscopically under oil immersion lens. The rate of Parasitaemia was estimated by the percent of infected red blood cells. Lymph node smears were done before and 2 weeks after treatment and lymphocytes were examined for shizonts (Koch' $s$ blue bodies). Two blood samples were collected from each calf before and after treatment. Each sample was put in two tubes. The first contained Na-salt of EDTA as anticoagulant for haematological investigations. The second was left without anticoagulant to separate serum for biochemical analysis.

\section{- Therapeutic application:}

The infected groups (A\&B) which showed the signs of T. annulata infection and positive by blood films examination were injected intramuscularly with Butalex (Buparvaquone, BW 720 C, Essex Animal Health, Friesoythe, Germany) at a dose rate of $2.5 \mathrm{mg} / \mathrm{kg}$ bodyweight (Dhar et al., 1988) in a single dose for group A and double dose with $48 \mathrm{~h}$ interval for group B. Clinical examination was carried out on the treated calves daily for 20 days. 


\section{- Haematological investigations:}

Haematological investigation including erythrocytic count (RBC), haemoglobin $(\mathrm{Hb})$, packed cell volume (PCV) and total leucocytic count (TLC) were done on whole blood according to Jain (1993).

\section{- Biochemical investigations:}

Blood serum was used for determination of total proteins, albumin, glucose,calcium, phosphorous, magnesium (Henry et al.,1974) cholesterol and triglycerides (Rifai and Wamick, 1993) using commercial test kits.

\section{- Recovery of infected cases:}

was indicated by the reduction in the percentage of erthrocytic piroplasms, disappearance of micro and macro-schizont in blood and lymph node smears in addition to remission of fever, recovery from clinical syndromes and the restoration of haematological and biochemical parameters.

\section{- Statistical analysis:}

The obtained data was statistically analyzed using the general liner model followed by student "t" test using a computerized $S A S$ (1989) program.

\section{RESULTS}

\section{Clinical and parasitological findings:}

Blood smears investigation revealed the presence of $\mathrm{T}$. annulata trophozoite inside red blood cells. Different forms of the parasite were found including ring and oval shape, which were predominant beside other forms as comma and rod shapes, which were not frequent. The RBC lost its symmetrical sphere and showed abnormal textures including echinocytosis and acanthocytosis (Photo 1). The Parasitaemia rate in the infected calves (the number of infected RBC / $100 \mathrm{RBC}$ ) ranged from $12-28 \%$. Microschizogony and macroschizogony of the lymphocytes were prevalent in the all examined blood (Photo 1) and lymph smears (Photo 2). According to the morphological criteria of the erythrocytic Kafr El-Sheikh Vet. Med. J. Vol. 1 No. 2 (2003) 
stages and the presence of shizonts in circulating lymphocytes, theileria species during this work was identified as T.annulata. Rectal temperature was elevated in all infected animals up to $40.5-41.3^{\circ} \mathrm{C}$. The visible mucous membranes were severely congested with lacrimation and the prescapular lymph nodes were enlarged. Some individuals showed respiratory distresses, icterus, diarrhoea and recumbence. After treatment, rectal temperature remained elevated $\left(40-40.6^{\circ} \mathrm{C}\right)$ for $5-8$ days in single dose injected calves; lymph nodes did not restore their actual size and parasitaemia declined slowly till it reached its minimal level $(4.5 \%)$ at the day 20 post treatment (PT).Microschizogony andmacroschizogony of the lymphocytes remained prevalent in all the examined blood and lymph smears. Also, 2 calves were died at the day 7 and 8 post treatment (PT). After showing a relatively higher rate of parasitaemia (33-41\%), which did not reduce after treatment. Rectaltemperature remained between $41.2-41.6^{\circ} \mathrm{C}$ till death.In double dose injected calves, the temperature was subsided 1-2 days after the second dose, lymph nodes restored their normal size after 3-4 days, and the rate of parasitaemia reached to less than $1 \%$ at the day 12 PT(Table 1 and Figure1).

\section{Haematological and biochemical findings:}

Haematological studies of infected calves (Table 2 and Figure2) revealed severe anaemia, which wasmanifested byhighlysignificant reduction in $\mathrm{RBC}, \mathrm{Hb}$ and PCV. Total leucocytic count showed severe leucopenea. After treatment, these parameters were not restored in calves received singledose.Animals which were received double dose showed restoration of RBC, $\mathrm{Hb}$ and PCV values, but the values of TLC were not restored.

The biochemical investigations (Table 3 and Figures 3,4,5) showed severe reduction in the concentrations of total protein, albumin, globulin, glucose, cholesterol, calcium and phosphorous in infected calves if compared with non infected control group, while triglycerides and magnesium concentrations did not show significant variations. After treatment, the values of total protein, albumin, globulin and phosphorous in group A (which received single dose) not returned to normal while the values of cholesterol, calcium and magnesium were restored. In group B (which received double dose), the values of biochemical parameters were restored to their normal values and did not showe significant variation compared to the healthy control animals except the value of globulin concentration, which remain lower than controls.

Kafr El-Sheikh Vet. Med. J. Vol. 1 No. 2 (2003) 


\section{DISCUSSION}

Diagnosis of clinical cases of acute theileriasis is fairly simple, and farmers recognize the disease with little difficulty. Fever accompanied by enlargement of the superficial lymph nodes during tick season, is strongly suggestive of the disease (Radostits et al., 2000). Symptoms that appeared in this study indicated the affection of these animals with theileriasis, which were confirmed by the demonstration of the trophozoites and schizogony stages in Giemsa's stained blood smears in addition to micro and macroschizonts in lymph node smears. The prevalence of erythrocytic stages and the morphological criteria proved that the species of theileria is T.annulata, also the presence of shizonts (Koch's blue bodies) in circulating lymphocytes confirmed these findings (Levine, 1985).

Cattle treated with buparvaquone are considered cured when their body temperature return to normal and trophosoite fall to less than $1 \%$ (Dhar et al., 1987). In the present work, the rectal temperature of calves injected with single dose of buparvaquone (group A) remained elevated for 5-8 days and parasitaemia reached $4.5 \%$ at day 20 PT. However, in the double dose treated group (group B), the pyrexia subsided in the second or the third day and the rate of parasitaemia reached to less than $1 \%$ at day 12. So that, according to Dhar et al. (1987) the animals in group B are considered cured at day 12 while those in group A were considered not fully cured even at day 20 PT.In India, deaths due to anaemia occurred in calves treated with single dose of $2.5 \mathrm{mg} / \mathrm{kg} \mathrm{BW}$ buparvaquone (Dhar et al., 1988), while the recovery percent reached $88.7 \%$ with 3 doses at 48 hours interval in Iran. On the other hand a group of calves in those treated in India were fully cured at day 12 after single dose (Sharma and Mishra, 1990). Singh, et al. (1993b) reported $100 \%$ effectiveness of buparvaquone at $2.5 \mathrm{mg} / \mathrm{kg} \mathrm{BW}$ in juvenile and adult cattle while it was $96 \%$ in neonates. In the present work, 2 calves were died of anaemia aftertreatment with single dose. The obtained results point to the fact that the drug at the dose rate $2.5 \mathrm{mg} / \mathrm{kg} \mathrm{BW}$ was not fully effective on the local strain in the study area.

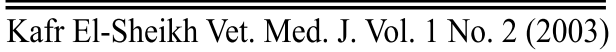


Infected calves in this study showed severe reduction of the haematological parameters including $\mathrm{RBC}, \mathrm{Hb}$ and $\mathrm{PCV}$. These results coincide with the reports of Urquhart et al. (1996), Sandhu et al.(1998) and Omer et al. (2002). Hooshmand-Rad (1976) postulated that, in T. annulata infection,erythrocytic forms as well as schizonts contribute to theanaemia although the role played by schizonts is greater, and the involvement of an autoimmune reaction is proposed. Recently, Sahoo et al. (2001) found increased levels of malonaldehyde which is an end product of lipid peroxidation in the erythrocytes of calves infected with T.annulata, which may enhance haemolysis and fragility of these cells. The present work showed that this reduction was restored after treatment by double dose of the drug while it remain significantly reduced after treatment by single dose. These results were parallel to the rate of parasitaemia in both groups. Similar results were obtained by Dhar et al. (1988) who found that 4 out of 5 calves were anaemic after single dose of buparvaquone, while Singh et al. (1993a) found more and rapid recovery of anaemia in calves injected with a $5 \mathrm{mg} / \mathrm{kg}$ BW single dose.

The present work showed severe reduction in the mean values of total leucocytic count in infected calves. Earlier studies revealed progressive leucocytosis during T. annulata infections(Uilenberg,1981 and Vercruysse et al., 1988) in spite of reports on leucopenea (Prasad, 1946 and Laiblin, 1978). However, studies of Preston et al. (1992) revealed that leucopenia was a characteristic and prompt response to both lethal and sublethal infections by T. annulata in cattle, which agree with the current results. The authors provided evidences of prompt radical reduction of the circulating lymphocytes and neutrophils, which led to panleucopenia.

After treatment, the current study showed that leucopenia was not corrected in both infected groups (either after one or double dose treatments). These results can be supported by the findings of Volker et al. (2001) who reported that the specific elimination of the parasite in vivo and in vitro by the use of the theilericidal drug, BW720c results in growth arrest of the host cells and the transformed phenotype of infected cells can be reversed. 
The present work revealed severe reduction in blood serum metabolites incalves infected with T.annulata.Smith(1996), Urquhart et al. (1996) and Radostits et al. (2000) reported that Theileria annulata is a deleterious debilitating disease, which can produce serious problems in different organs in the body. The reduction of blood serum albumin concentration in the present work agree with the previous reports cited by Sandhu etal. (1998) and Omeret al.(2003). Anorexia as well as intestinal troubles and diarrhoea may be responsible for such reduction (Kaneko,1997 and Thomas, 2000). Moreover, Sandhu et al. (1998) reported liver involvement during T. annulatadestruction of body organs, leading to disturbances in biosynthesis in the liver (Laiblin et al, 1978) which may be a contributable factor for albumin reduction.

The mean values of blood serum globulin showed highly significant reduction during $\mathrm{T}$. annulata infection in the current work. These results coincide with the reduction of total leucocytic count, which are responsible for the production of immunoglobulins, the main component of serum globulin(Thomas, 2000). Similar results were obtained by Omer et al.(2003).

The reduced mean values of serum total proteins was resulted from the initiated hypoalbuminaemia and hypoglobulinaemia. Omer et al. (2003) noticed also hypoproteinaemia in naturallyinfected calves with T. annulata. Both total protein and albumin concentrations remained significantly reduced in treated group A, while they restored their normal values in group B when compared to the healthy control group. These results may be correlated with the levels of parasitaemia in both groups after treatment, which remained at higher levels in group A. On the other hand, the mean values of globulin concentrations did not return to their normal values in both groups after treatments. Previous studies ensured that infected cattle with T. annulata are not fully cured after recovery and act as carriers (Urquhart et al., 1996 and Radostits et al., 2000). The parasites may present in about $10 \%$ of dormant lymphocytes in the lymph nodes (Ahmed et al., 1989). These infected cells may activate natural killer cells and macrophages that kill their target lymphocytes (Ahmed and Mehlhorn, 1999) with a subsequent loss of immunoglobulins and in turn total globulins. 
The mean values of serum glucose levels were severely reduced in both infected groups in this study. Yadav and Sharma (1986) obtained similar results. This can be attributed to the drastic effects of the parasite on the liver(Smith,1996) which may inhibit gluconeogenesis or glycogen stores which are essential for the maintenance of blood glucose (Tenant, 1997). Similarly, infected calves in the current study showed significant reduction in the mean values of blood serum cholesterol in both infected groups. These results coincide with the reports of Sandhu et al. (1998). The impaired assimilation of fatty acids in the injured liver and the defect of lipids absorption in the inflamed intestine (Radostits et al., 2000) may be the real factors causing cholesterol reduction.

Both blood serum calcium and phosphorous concentrations in the present work were significantly decreased in both infected groups. These results are in agreement with those reported by Yadav and Sharma (1986) and Omer et al. (2003). The kidney dysfunction during theileria infection (Radostits et al., 2000) in addition to anorexia and impairment of absorption of these minerals in the intestine (Sandhu et al., 1998) might contribute to these reductions. It was noticed that the reduced concentrations of glucose, cholesterol,calcium and phosphorous were restored their normal levels after treatment in both groups.

Finally,itcan be declared that T. annulata infection is a drastic disease affecting the general health of crossbred cattle in tropical areas. Although buparvaquone is the drug of choice in treatment of theileriasis worldwide, it must be given in double doses of $2.5 \mathrm{mg} / \mathrm{kg} \mathrm{BW}$ each, with $48 \mathrm{~h}$ interval for a successful therapeutic eradication of the parasite in Upper Egypt.

\section{REFERENCES}

- Ahmed, J. S and Mehlhorn H. (1999): Review: the cellular basis of the im-munity to and immunopathogenesis of tropical theileriosis. Parasitol Res. 85: 539-549.

- Ahmed, J. S; Rothert, M; Steuber, S. and Schein, E. (1989): In vitro proli-ferative andcytotoxicresponses of PBL from Theileria annulata-immune cattle. Zentralbl Veterinarmed [B] 36: 584-592.

$\overline{\text { Kafr El-Sheikh Vet. Med. J. Vol. } 1 \text { No. } 2 \text { (2003) }}$ 
- Brown, C. G. (1990): Control of tropical theileriosis (Theileria annulata inf-ection) of cattle. Parassitologia; 32: 23-31.

- Daubney, R. and Sami, S. M. (1951): Egyptia fever in cattle. Transmission of Theileria annulata by Hyalomma excavatum. Parasitology, 41: 249-260.

- Dhar, S; Malhotra, D. V; Bhushan, C. and Gautam, O. P. (1990): Chemo-immunoprophylaxis against bovine tropical theileriosis in young calves: a comparison between buparvaquone and long-acting oxytetracycline. Res Vet Sci. 49: 110-112.

- Dhar, S; Malhotra, D. V; Bhushan, C. and Gautam, O. P. (1987): Buparv-aquone(BW720 C)for the treatment of bovine tropical theileriosis. Proceedings of the Inaugural Symposium. Indian Association for the Advancement of Veterinary Parasitology. IVRI, Izatnagar, Feb 12-13th 1987, pp 31-32.

- Dhar, S;Malhotra, D.V; Bhushan, C. and Gautam, O. P. (1988): Treatment of experimentally induced Theileria annulata infection in crossbred calves with buparvaquone. Vet Parasitol 27: 267-275.

- Henry,R.J.,Cannon,D.C., and Winkelman, J.W. (1974): Clinical chemistery, Principles and techniques.4th Ed., Haroer \&Row; Hagerston M. D.

- Hooshmand-Rad P.(1976): The pathogenesis of anaemia in Theileria annulata infection. Res Vet Sci. 20: 324-329.

- Jain, N. C. (1993): Essentials of Veterinary Hematology, 1st Ed.Lea\& Febiger, and Philadelphia.

- Kaneko J. J. (1997): Serum Proteins and Dysproteinemias. In: Clinical Bio-chemistry of Domestic Animals. Eds. Kaneko, J.J; Harvey, J.W. and Bruss, M.L; 5th Ed. Academic press, London. pp. 117-138.

- Laiblin, C.(1978): Klinische untersuchungen zur Theileria annulata infektion des rinders. Berl. Munch. Tierarztl. Wochenschr. 91: 4850.

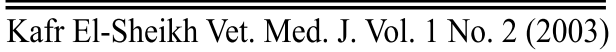


- Laiblin, C;Baysu, N. and Muller, M. (1978): Clinical study on ovnorimantal Thailarin annulnts infantions of cattle.1.Clinicalhr. 91: 25-27.

- Levine, N.D. (1985): Piroplasma in "Veterinary protozoology Iowa State Univ. Press, Ames Iowa USA chapter 11 pp: 313 - 326.

- Omer, O. H; El-Malik, K. H; Magzoub, M; Mahmoud, O. M; Haroun, E. M; Hawas, A. and Omar, H. M. (2003): Biochemical profiles in Friesian cattle naturally infected with Theileria annulata in Saudi Arabia. Vet Res Commun 27: 15-25

- Omer, O. H; El-Malik, K. H; Mahmoud, O. M; Haroun, E. M; Hawas, A; Sweeney, D. and Magzoub, M. (2002): Haematological profiles in purebred cattle naturally infected with Theileria annulata in Saudi Arabia. Vet Parasitol 107: 161-168.

- Prasad, B. M. (1946): Morphological studies of the blood of bulls in health and during acute theileriasis. Ind. J. Vet. Sci. Anim. Husb. 16: 54-56.

- Preston,P.M; Brown, C. G; Bell-Sakyi, L; Richardson, W. and Sanderson, A.(1992): Tropical theileriosis in Bos Taurus and Bos Taurus cross Bos indicus calves: response to infection with graded doses of sporozoites of Theileria annulata. Res Vet Sci. 53: 230-243.

- Radostits,O. M; Blood, D.C. and Gay, C.C. (2000): Veterinary Medicine, 8th Ed. Baillier Tindall, London. pp 1230.

- Refaii, A. H. and Michael, S. A. (1976): The application of Imidocarb Dip-ropionate for the control of Theileria annulata infection in Egyptian cattle used for testing Renderperst vaccine. Br. Vet. J. 132: 363-368.

- Rifai, N.and Wamick, G. R.(1993): Laboratory measurement of lipids, lipo-proteins and apolipoproteins. AACC press, Washington DC. 
- Sahoo, A; Patra, R. C; Pathak, N. N; Dwivedi, S. K. and Dash, P. K. (2001): Enhanced lipid peroxide levels in the erythrocytes of calves with haemoglo-binurea. Vet Res Commun. 25: 55-59.

- Sandhu,G.S; Grewal, A.S; Singh, A; Kondal, J. K; Singh, J. and Brar, R. S. (1998): Haematological and biochemical studies on experimental Theileria annulata infection in crossbred calves. Vet Res Commun 1998. 22: 347-354.

- $\quad S A S$ (1989):SAS/STAT, uide for personalcomputer,S C,USA.

- Sharma,.N.and Mishra,A.K. (1990): Treatment of bovine tropical theileriosis with buparavaquone. Trop. Anim. Hlth. Prod. 22: 63-65.

- Singh, D. K; Thakur, M; Raghav, P. R. and Varshney, B. C. (1993a): Chemothe-rapeutic trials with four drugs in crossbred calves experimentally infected with Theileria annulata. Res Vet Sci 54: 6871

- Singh, J; Gill, J. S; Kwatra, M. S. and Sharma, K. K. (1993b): Treatment of theileriosis in crossbred cattle in the Punjab. Trop. Anim.Hlth.Prod.25:75-78.

- Smith, B. P. (1996): Large animal internal medicine, 2nd Ed., (Mosby-Year book, Inc., St. Louis).

- Tenant,B.C.(1997): Hepatic function. In Clinical Biochemistry of Domestic Animals.5th ed.Kaneko,J.J.,Harvey,J. W. and Bruss, M. L., Academic press, London.

- Thomas, J. S. (2000): Overview of Plasma Proteins. In Schalm's Veterinary Hematology.5th Ed.Feldman,B.F;Zinkl,J.G.and Jain, N.C.,Lippincott Willi-ams \& Wilkins, Philadelphia, Baltimore. pp. 891-898.

- Uilenberg,G.(1981):Theileria infection other than East CoastFever.In Diseases of cattle in the tropics. Ed. M. Ristic and I. Mclntyre. The Hague. Martinus Nijhhoff. pp. 411-427. 
- Urquhart,G. M.;Armour, J;Duncan,J. L; Dunn, A. M. and Jennings, $\boldsymbol{F}$. W. (1996): Veterinary parasitology, 2nd ed., Blackwell Science.

- Vercruysse, J; Taraschewski, H. and Voigt, W. P. (1988): Main clinical and pathological signs of parasitic infections in animals. In Parasitology in Focus. Facts and Trends. Ed. H. Mehlhorn. Berlin. Springer- Verlag. pp. 516-519.

- Volker,T.H;Peter K.andSven,R.(2001): Inhibition of apoptosis by intracell-ular protozoan parasites. Invited review. International Journal for Parasitology (2001) 31: 1166-1176

- Yadav, C. L. Sharma, N. N. (1986): Changes in blood chemical nomnonante durino ovnorimantally indunod Theileria annulata

Table(1):Patterns of parasitaemia (\%) after treatment by buparvaquone in single dose injected (group A) and double dose injected (group B) calves.

\begin{tabular}{||c||c||c||c||c||c||c||}
\hline & $\begin{array}{c}\text { Before } \\
\text { treat. }\end{array}$ & $\begin{array}{c}4^{\text {th }} \text { day } \\
\text { after } \\
\text { treat. }\end{array}$ & $\begin{array}{c}8^{\text {th }} \text { day } \\
\text { after } \\
\text { treat. }\end{array}$ & $\begin{array}{c}12^{\text {th }} \text { day } \\
\text { after } \\
\text { treat. }\end{array}$ & $\begin{array}{c}16^{\text {th }} \text { day } \\
\text { after } \\
\text { treat. }\end{array}$ & $\begin{array}{c}20^{\text {th }} \text { day } \\
\text { after } \\
\text { treat. }\end{array}$ \\
\hline \hline Group (A) & 19.75 & 15.63 & 12.13 & 9.13 & 6.25 & 4.50 \\
& \pm 1.87 & \pm 1.10 & \pm 0.85 & \pm 0.72 & \pm 0.94 & \pm 0.68 \\
\hline \hline Group (B) & 21.88 & 8.75 & 3.13 & 0.82 & - & - \\
& \pm 1.63 & \pm 0.59 & \pm 0.48 & \pm 0.08 & & \\
\hline
\end{tabular}

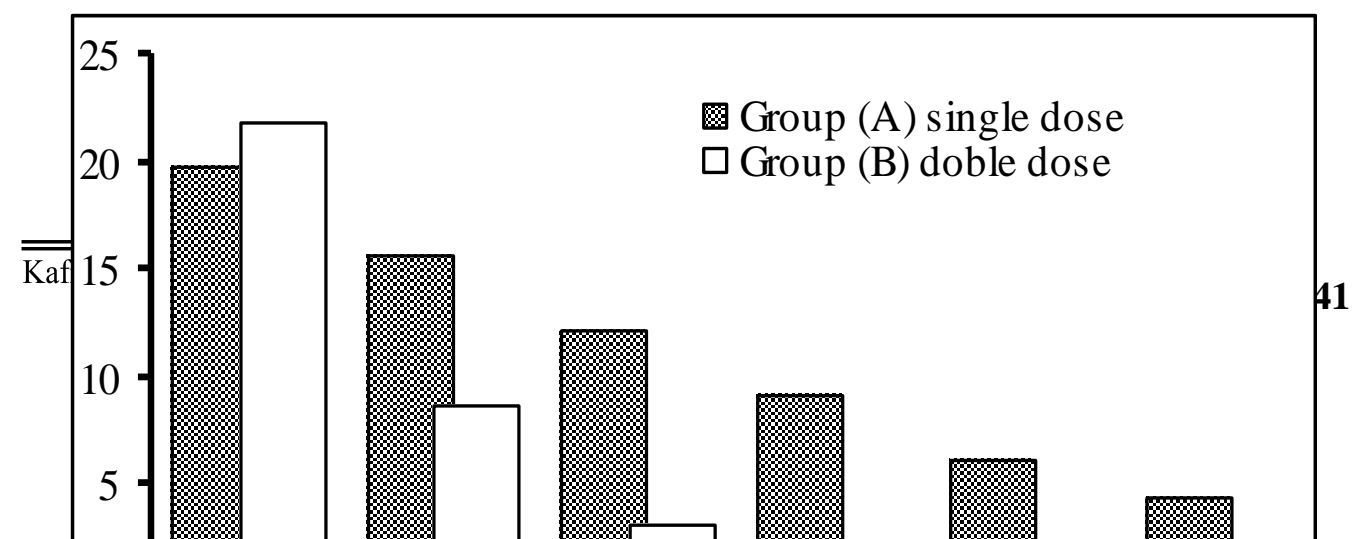


Figure (1): levels of parasitaemia (\%) in cross bred calves infected with $\mathrm{T}$. annulata before and after treatment with buparvaquone in a single dose (group A) and double dose (group B).

Table(2): Haematological parameters (mean \pm SD) in control and infected calves with $\mathrm{T}$. annulata before and after treatment with buparvaquone in a single dose (group A) or double dose (group B).

\begin{tabular}{|c|c|c|c|c|c|c|}
\hline \multirow[b]{2}{*}{ Parameter } & \multirow[b]{2}{*}{ Unit } & \multirow{2}{*}{$\begin{array}{c}\text { Control } \\
\text { group }\end{array}$} & \multicolumn{2}{|c|}{ Infected group A } & \multicolumn{2}{|c|}{ Infected group B } \\
\hline & & & $\begin{array}{c}\text { Before } \\
\text { treat. }\end{array}$ & $\begin{array}{l}\text { After } \\
\text { treat. }\end{array}$ & $\begin{array}{c}\text { Before } \\
\text { treat. }\end{array}$ & $\begin{array}{l}\text { After } \\
\text { treat. }\end{array}$ \\
\hline $\mathrm{RBC}$ & $x 10^{6} / \mu l$ & $\begin{array}{c}8.17 \\
\pm 0.35\end{array}$ & $\begin{array}{c}4.85 \\
\pm 0.29^{* * * *}\end{array}$ & $\begin{array}{c}6.78 \\
\pm 0.37 *\end{array}$ & $\begin{array}{c}5.16 \\
\pm 0.30^{* * * *}\end{array}$ & $\begin{array}{c}7.99 \\
\pm 0.43\end{array}$ \\
\hline $\mathrm{Hb}$ & $\mathrm{gm} / \mathrm{dl}$ & $\begin{array}{c}9.37 \\
\pm 0.37\end{array}$ & $\begin{array}{c}5.19 \\
\pm 0.37 * * *\end{array}$ & $\begin{array}{c}7.76 \\
\pm 0.44^{*}\end{array}$ & $\begin{array}{c}4.98 \\
\pm 0.33 * * *\end{array}$ & $\begin{array}{c}8.21 \\
\pm 0.55^{\text {ns }}\end{array}$ \\
\hline PCV & $\%$ & $\begin{array}{r}34.43 \\
\pm 1.49 \\
\end{array}$ & $\begin{array}{c}22.88 \\
\pm 1.53^{* * * *} \\
\end{array}$ & $\begin{array}{c}28.38 \\
\pm 1.44 * \\
\end{array}$ & $\begin{array}{c}24.25 \\
\pm 1.60^{* * * *} \\
\end{array}$ & $\underset{\mathrm{ns}}{30.88 \pm 1.47}$ \\
\hline TLC & $x 10^{3} / \mu l$ & $\begin{array}{c}7.39 \\
\pm 0.33 \\
\end{array}$ & $\begin{array}{c}5.03 \\
\pm 0.26^{* * * *}\end{array}$ & $\begin{array}{c}6.36 \\
\pm 0.32 *\end{array}$ & $\begin{array}{c}4.75 \\
\pm 0.27 * * *\end{array}$ & $\begin{array}{c}6.04 \\
\pm 0.43 *\end{array}$ \\
\hline
\end{tabular}

Superscripts are the levels of significance between infected groups either before or after treatment and the control healthy group: ns: non-significant, ${ }^{*}, *, * * *: \mathrm{P} \leq 0.05,0.01$ and 0.001 respectively.

Table (3): Mean values \pm SD of blood serum metabolites in control and infected calves with $\mathrm{T}$. annulata before and after treatment with buparvaquone in a single dose (group A) or double dose (group B).

\begin{tabular}{|c|c|c|c|c|c|c|}
\hline \multirow[b]{2}{*}{ Metabolite } & \multirow[b]{2}{*}{ Unit } & \multirow[b]{2}{*}{$\begin{array}{l}\text { Control } \\
\text { group }\end{array}$} & \multicolumn{2}{|c|}{ Infected group A } & \multicolumn{2}{|c|}{ Infected group B } \\
\hline & & & $\begin{array}{c}\text { Before } \\
\text { treat. }\end{array}$ & $\begin{array}{l}\text { After } \\
\text { treat. }\end{array}$ & $\begin{array}{c}\text { Before } \\
\text { treat. }\end{array}$ & $\begin{array}{l}\text { After } \\
\text { treat. }\end{array}$ \\
\hline
\end{tabular}

Kafr El-Sheikh Vet. Med. J. Vol. 1 No. 2 (2003) 


\begin{tabular}{|c|c|c|c|c|c|c|}
\hline T. proteins & $g m / d l$ & $\begin{array}{c}6.53 \\
\pm 0.37 \\
\end{array}$ & $\begin{array}{c}4.58 \\
\pm 0.27 * * \\
\end{array}$ & $\begin{array}{c}5.30 \\
\pm 0.23 * \\
\end{array}$ & $\begin{array}{c}4.65 \\
\pm 0.24 * * \\
\end{array}$ & $\begin{array}{c}5.68 \\
\pm 0.16^{\text {ns }} \\
\end{array}$ \\
\hline Albumin & $g m / d l$ & $\begin{array}{c}3.20 \\
\pm 0.14\end{array}$ & $\begin{array}{c}2.29 \\
\pm 0.19 * *\end{array}$ & $\begin{array}{c}2.73 \\
\pm 0.12 *\end{array}$ & $\begin{array}{c}2.34 \\
\pm 0.19 * *\end{array}$ & $\begin{array}{c}3.05 \\
\pm 0.12^{\text {ns }} \\
\end{array}$ \\
\hline Globulin & $\mathrm{gm} / \mathrm{dl}$ & $\begin{array}{c}3.33 \\
\pm 0.27 \\
\end{array}$ & $\begin{array}{c}2.29 \\
\pm 0.19 * *\end{array}$ & $\begin{array}{c}2.58 \\
\pm 0.17 *\end{array}$ & $\begin{array}{c}2.31 \\
\pm 0.16^{* *}\end{array}$ & $\begin{array}{c}2.63 \\
\pm 0.14^{*}\end{array}$ \\
\hline Glucose & $m g / d l$ & $\begin{array}{r}61.0 \\
\pm 3.74 \\
\end{array}$ & $\begin{array}{c}46.50 \\
\pm 2.11 * * \\
\end{array}$ & $\begin{array}{c}59.74 \\
\pm 4.03 \\
\end{array}$ & $\begin{array}{c}48.75 \\
\pm 1.91^{*} \\
\end{array}$ & $\begin{array}{r}62.25 \\
\pm 3.51^{\mathrm{ns}} \\
\end{array}$ \\
\hline Cholesterol & $m g / d l$ & $\begin{array}{r}79.43 \\
+5.06 \\
\end{array}$ & $\begin{array}{c}98.38 \\
\pm 3.85^{*} \\
\end{array}$ & $\begin{array}{c}81.75 \\
\pm 4.62^{\text {ns }}\end{array}$ & $\begin{array}{c}101.3 \\
\pm 5.06 * * \\
\end{array}$ & $\begin{array}{c}80.63 \\
\pm 5.43^{\mathrm{ns}} \\
\end{array}$ \\
\hline Triglyceride & $I U / l$ & $\begin{array}{r}113.4 \\
\pm 7.13 \\
\end{array}$ & $\begin{array}{c}99.38 \\
\pm 6.71^{\mathrm{ns}} \\
\end{array}$ & $\begin{array}{c}105.6 \\
\pm 7.01^{\mathrm{ns}} \\
\end{array}$ & $\begin{array}{c}112.8 \\
\pm 6.79^{\mathrm{ns}} \\
\end{array}$ & $\begin{array}{r}115.5 \\
\pm 5.65^{\mathrm{ns}} \\
\end{array}$ \\
\hline Calcium & $m g / d l$ & $\begin{array}{c}9.87 \\
\pm 0.38 \\
\end{array}$ & $\begin{array}{c}8.74 \\
\pm 0.31\end{array}$ & $\begin{array}{c}9.17 \\
\pm 0.34^{\mathrm{ns}} \\
\end{array}$ & $\begin{array}{c}8.87 \\
\pm 0.20^{*} \\
\end{array}$ & $\begin{array}{c}9.26 \\
\pm 0.42^{\mathrm{ns}} \\
\end{array}$ \\
\hline Phosphorous & $m g / d l$ & $\begin{array}{r}4.29 \\
\pm 0.25 \\
\end{array}$ & $\begin{array}{r}3.11 \\
\pm 0.19^{* *} \\
\end{array}$ & $\begin{array}{r}3.51 \\
\pm 0.17\end{array}$ & $\begin{array}{c}3.37 \\
\pm 0.20\end{array}$ & $\begin{array}{c}3.84 \\
\pm 0.19^{\text {ns }}\end{array}$ \\
\hline Magnesium & $m g / d l$ & $\begin{array}{c}2.63 \\
\pm 0.16\end{array}$ & $\begin{array}{c}2.41 \\
\pm 0.16^{\mathrm{ns}}\end{array}$ & $\begin{array}{c}2.55 \\
\pm 0.15^{\text {ns }}\end{array}$ & $\begin{array}{c}2.38 \\
\pm 0.14^{\mathrm{ns}} \\
\end{array}$ & $\begin{array}{c}2.59 \\
\pm 0.16^{\mathrm{ns}} \\
\end{array}$ \\
\hline
\end{tabular}

and the control healthy group:ns: non-signiticant, ${ }^{*},{ }^{* *},{ }^{* * *}: \mathrm{P} \leq 0.05,0.01$ and 0.001 respectively.

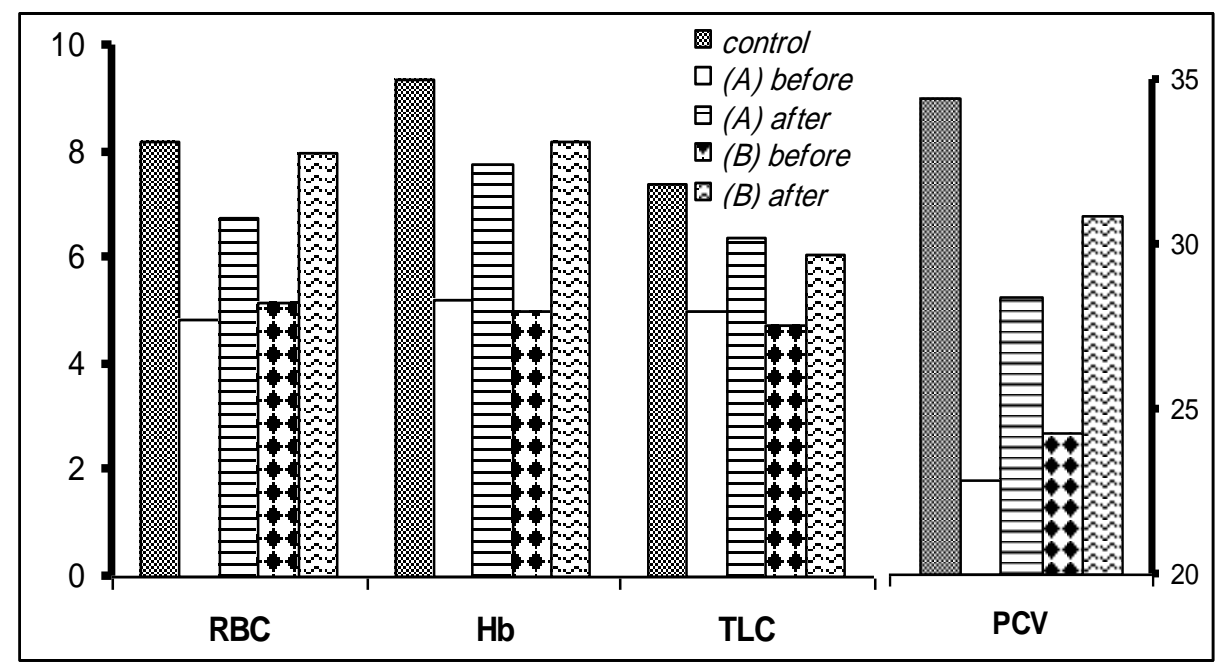

Figure (2): Haematological parameters:RBC (x106/ $\mu \mathrm{l}), \mathrm{Hb}(\mathrm{g} / \mathrm{dl}), \mathrm{PCV}(\%)$ and TLC $(x 103 / \mu 1)$ in cross bred calves infected with T.annulata before and after treatment with buparvaquone in a single dose(group A)and double dose (group B).

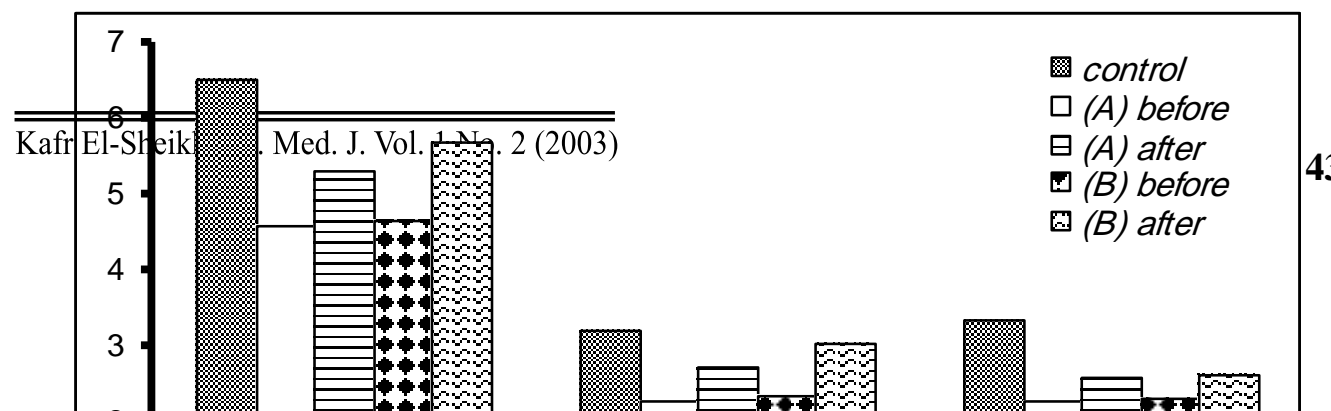


Figure (3): Mean values of blood serum protein, albumin and globulin (g/dl) in cross bred calves infected with $\mathrm{T}$. annulata before and after treatment with bup-arvaquone in a single dose (grou (group B).

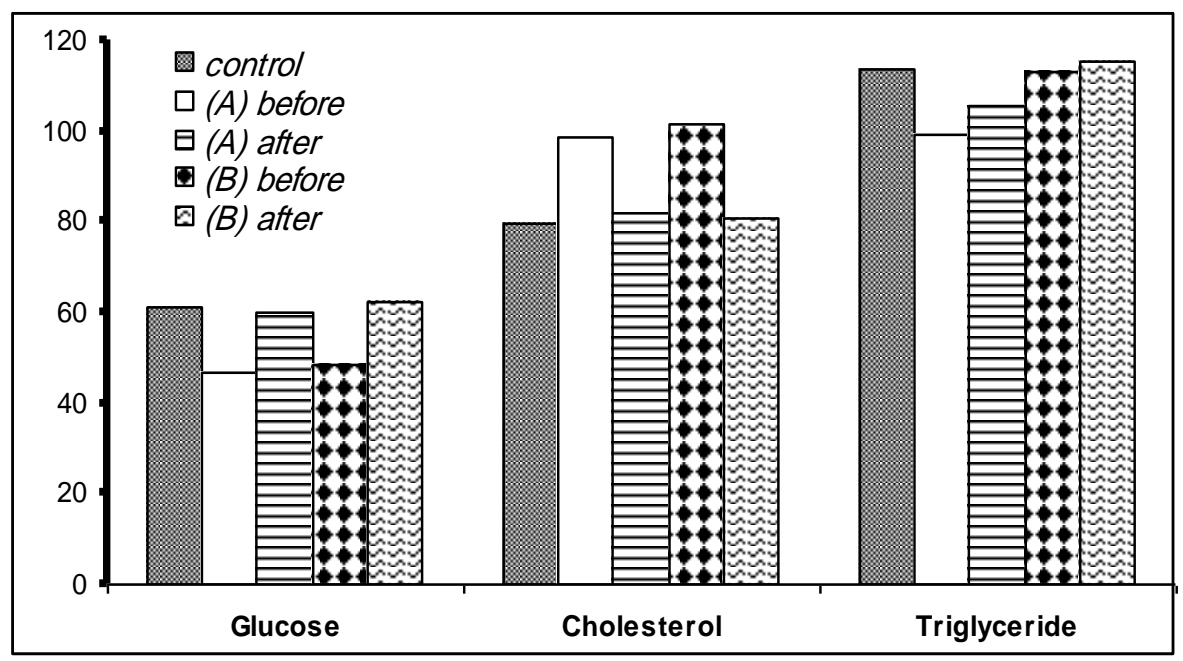

Figure (4): Variations in blood serum glucose, cholesterol and triglycerides $(\mathrm{mg} / \mathrm{dl})$ in cross bred calves infected with T. annulata before and after treatment with buparvaquone in a single dose (group A) and double dose (group B).

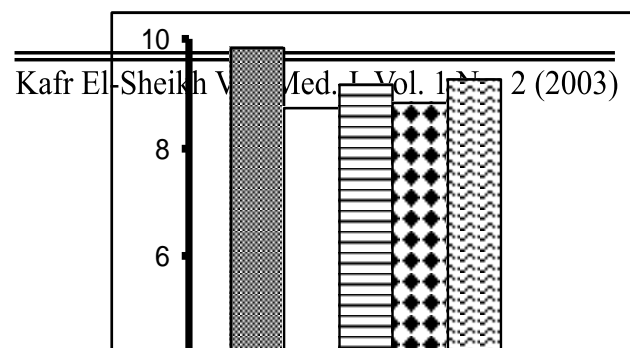


Figure (5): Variations in blood serum Ca,P, and $\mathrm{Mg}(\mathrm{mg} / \mathrm{dl})$ in cross bred calves infected with $\mathrm{T}$. annulata before and after treatment with buparvauble dose (group B).

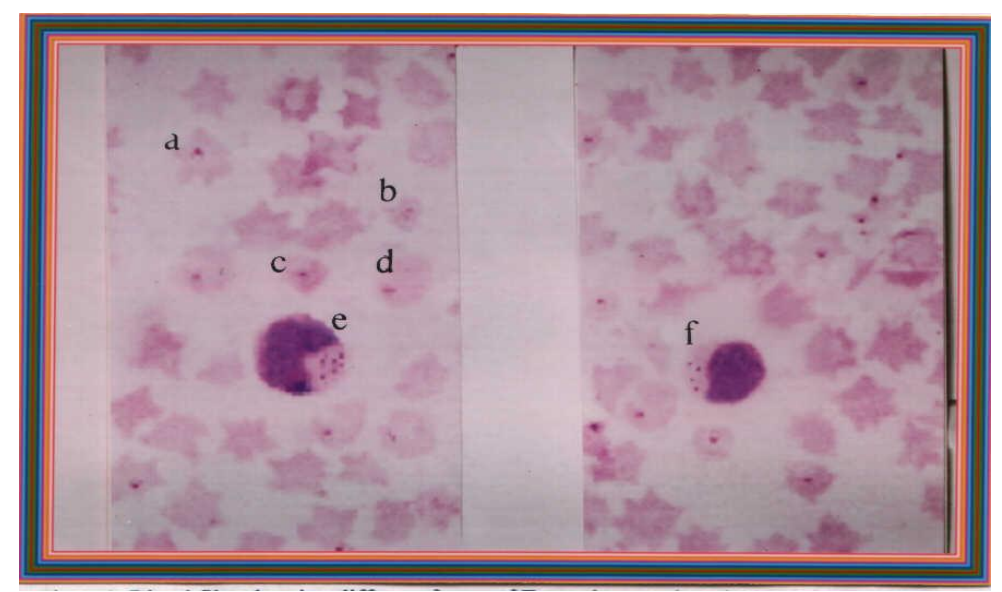

Photo(1): Blood film showingdifferentforms of T.annulata trophozoites (a-ring b-oval c-commad-rod) with circulating macro(e)and micro(f)shizonts, in addition to abnormal texture of the erythrocytes.

$\overline{\overline{\text { Kafr El-Sheikh Vet. Med. J. Vol. } 1 \text { No. } 2 \text { (2003) }}}$ 


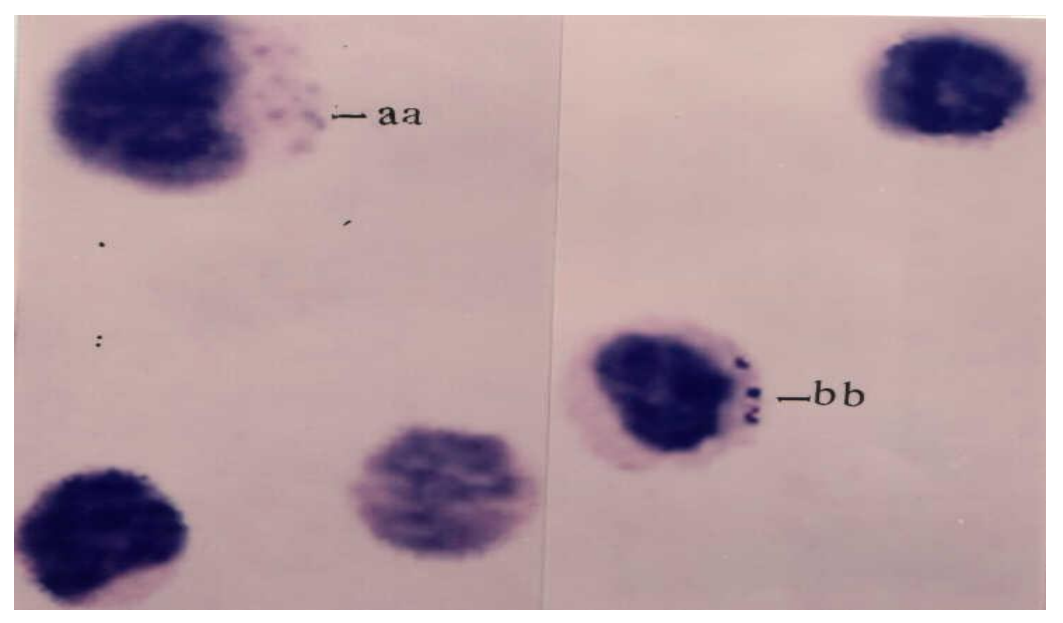

Photo(2):Lymphnodesmearshowing macro(aa)and micro(bb)shizogony stages.

در اسات علي الإصابة بالثيليريا في العجول الخليط قبل وبعد العلاج

بالبيوبارفاكون تحت تأثنير الظروف الإسلير فحلية في صعيد مصر.

\section{محمد عبد السلام ، ممدوح وجدي غطاس}

استهدفت هذه الدراسة تقدير الآثار الضارة للإصابة بالثليريا أنيولاتا على الحالة الصحية العامة

وعلى بعض المعايير الدموية والكيميائية وأيضـا تقييم كفاءة البيوبارفاكون كعلاج في العجول الخليط . وبدراسـة المقاسـات والأشكال المختلفة للطفيـل أكدت أنه يخص ثيليريـا انيولاتا0ـ تم حقن البيوبارفاكون بمعدل 2.5 مجم/كجم وزن حي كجرعة واحدة (مجموعة أ) أو جرعتين بينهما 48 ساعة (مجموعة ب). وصلت نسبة الإصـابة بالطفيل في العجول المصسابة إلى 12-28 \% كما ارتفعت درجة الحرارة إلى 41.3م وكانت الأنيميا هي الصفة السائدة مصحوبة بانخفاض في تركيز محتويات المصل من البروتين والألبيومين والجلوبيولين والجلوكوز والكوليستيرول والكالسيوم والفوسفور بينما لم تسجل تغيرات معنوية في تركيز الترايجليسرايد والماغنسيوم إذا ما قورنت بالمجموعة السليمة الضابطة. ظلت درجات الحرارة مرتفعة لمدة 5-8 أيسام كما انخفضت نسبة الإصـابة بالطفيل ببطيء حتى وصلت إلى أدنى مستوى إنى (4.5 \%) في اليوم العشرين بعد ا لعلاج في المجموعة الأولي. في هذه المجموعة أيضـا نفق عجلان Kafr El-Sheikh Vet. Med. J. Vol. 1 No. 2 (2003) 
في اليومين السابع والثنامن نتيجة ارتفاع درجة الحرارة ونسبة الإصـابة الثـديدة بالطفيل. كما أظهرت

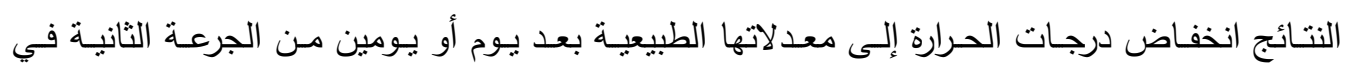

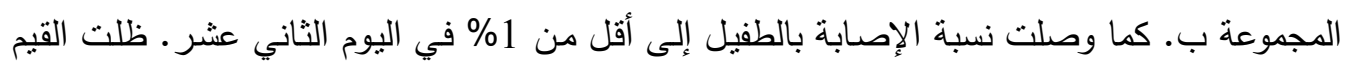

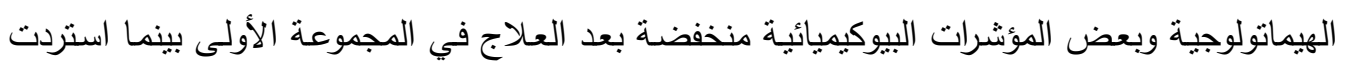

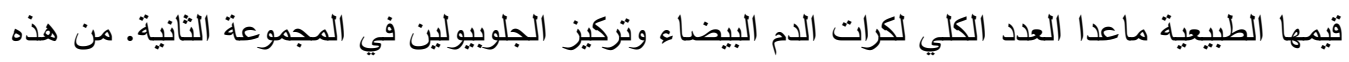

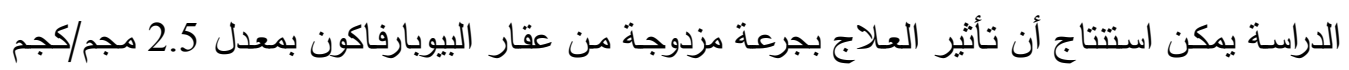

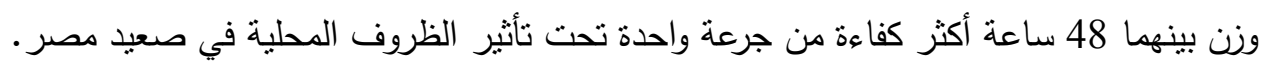

